ORIGINAL ARTICLE

\title{
Cell delivery of Met docking site peptides inhibit angiogenesis and vascular tumor growth
}

\author{
AR Cantelmo ${ }^{1}$, R Cammarota ${ }^{1}$, DM Noonan ${ }^{1,2}$, C Focaccetti $^{1}$, PM Comoglio ${ }^{3}$, \\ M Prat ${ }^{4,5}$ and A Albini ${ }^{1}$ \\ ${ }^{1}$ Oncology Research, Science and Technology Pole, Casa di Cura MultiMedica-IRCCS, Milan, Italy; ${ }^{2}$ Department of Experimental \\ Medicine, University of Insubria, Varese, Italy; ${ }^{3}$ Institute for Cancer Research and Treatment (IRCC), University of Turin Medical \\ School, Candiolo, Italy; ${ }^{4}$ Department of Medical Sciences, Università del Piemonte Orientale 'A Avogadro', Novara, Italy and \\ ${ }^{5}$ BRMA (Biotecnologie per la Ricerca Medica Applicata), Università del Piemonte Orientale 'A Avogadro', Novara, Italy
}

Hepatocyte growth factor (HGF) and its receptor Met are responsible for a wide variety of cellular responses, both physiologically during embryo development and tissue homeostasis, and pathologically, particularly during tumor growth and dissemination. In cancer, Met can act as an oncogene on tumor cells, as well as a pro-angiogenic factor activating endothelial cells and inducing new vessel formation. Molecules interfering with Met activity could be valuable therapeutic agents. Here we have investigated the antiangiogenic properties of a synthetic peptide mimicking the docking site of the Met carboxyl-terminal tail, which was delivered into the cells by fusion with the internalization sequences from Antennapedia or HIV-Tat. We showed that these peptides inhibit ligand-dependent endothelial cell proliferation, motility, invasiveness and morphogenesis in vitro to an even greater extent and with much less toxicity than the Met inhibitor PHA-665752, which correlated with interference of HGF-dependent downstream signaling. In vivo, the peptides inhibited HGF-induced angiogenesis in the matrigel sponge assay and impaired xenograft tumor growth and vascularization in Kaposi's sarcoma. These data show that interference with the Met receptor intracellular sequence impairs HGFinduced angiogenesis, suggesting the use of antidocking site compounds as a therapeutic strategy to counteract angiogenesis in cancer as well as in other diseases.

Oncogene (2010) 29, 5286-5298; doi:10.1038/onc.2010.267; published online 5 July 2010

Keywords: Met; cell-penetrating peptides; Antennapedia; Tat; angiogenesis; cancer

\section{Introduction}

Angiogenesis contributes to cancer initiation and progression and to several other pathologies, such as

Correspondence: Dr A Albini, MultiMedica Castellanza, Via Piemonte 70, Castellanza (VA) 21053, Italy or Oncology Research, Science and Technology Pole, Casa di Cura MultiMedica-IRCCS, Via Fantoli 16/15, Milano 20138, Italy.

E-mail: adriana.albini@multimedica.it

Received 14 January 2010; revised 28 April 2010; accepted 1 June 2010; published online 5 July 2010 chronic inflammation, retinopathies and arthritis (Carmeliet and Jain, 2000). The formation of a tumor-associated vasculature, a process referred to as tumor angiogenesis, is essential for cancer progression and metastasis and has become a clinical target for anticancer therapy. Current clinical approaches all focus on blocking a common hypoxia-associated angiogenic factor, vascular endothelial growth factor (VEGF), by either sequestering the factor itself or inhibiting its receptors. Although effective in slowing tumor progression, tumor escape through a variety of mechanisms, including up-regulation of other angiogenic growth factors, is frequently encountered (Loges et al., 2009).

The receptor for the human hepatocyte growth factor (HGF), encoded by MET oncogene, has an important physiological role in a complex morphogenetic program known as invasive growth, occurring both during embryonic development and during adult life. In pathological conditions, unregulated HGF-Met signaling can trigger tumor growth and metastasis (Boccaccio and Comoglio, 2006). Met is predominantly expressed by epithelial cells (Di Renzo et al., 1991; Prat et al., 1991), although it is also expressed in other cell types, including endothelial (Bussolino et al., 1992), myoblasts (Anastasi et al., 1997), hematopoietic (Nishino et al., 1995) and neuronal cells (Ebens et al., 1996). HGF binding triggers receptor activation through dimerization and auto/trans-phosphorylation of tyrosine residues. Two tyrosine residues within the catalytic loop $\left(\mathrm{Y}^{1234}, \mathrm{Y}^{1235}\right)$ are first to be phosphorylated, leading to full kinase activation (Longati et al., 1994). Subsequently, two other tyrosine residues $\left(\mathrm{Y}^{1349}, \mathrm{Y}^{1356}\right)$ in the carboxyl-terminal tail are phosphorylated. These are embedded in a multifunctional consensus sequence (Ponzetto et al., 1994), acting as a docking site for different SH2-containing transducers and adaptors involved in several pathways, including the GRB2SOS-RAS-RAF-MEK-ERK (extracellular signalregulated protein kinase) pathway, the phosphoinositide 3-kinase-AKT cascade, SRC, STAT3, SHC, PLC- $\gamma$, cbl, Gabl and Rho-like GTPases such as RAC1 (Birchmeier et al., 2003; Lock et al., 2003).

Different strategies to target Met have the aim of inhibiting tumor growth and metastatic dissemination 
(Comoglio et al., 2008). Met can be blocked by smallmolecule inhibitors, early examples for which are K252a (Morotti et al., 2002), SU11274 (Berthou et al., 2004) and PHA-665752 (Christensen et al., 2003), all of which compete for ATP binding to block Met catalytic activity. Several of these molecules (PF-2341066, XL880, ARQ197, MK2461, MP470, SGX523 and JNJ38877605) are in phase I/II clinical trials (Zou et al., 2007; Comoglio et al., 2008). Owing to the way in which they were selected and the inhibitory mechanism with which they operate, none of these drugs shows absolute specificity for Met, but also target other kinases, mostly receptor tyrosine kinases (Comoglio et al., 2008). Higher levels of specificity in Met inhibition can be obtained using biological molecules, either natural or designed expressly on the basis of the structure of HGF or Met. They act as antagonists that interfere in the ligand/receptor interaction, which normally leads to receptor dimerization and subsequent activation. HGF can be antagonized by its shorter forms: NK2 - a natural fragment of HGF, or NK4-a truncated form of HGF, or by its uncleavable form, all of which bind the receptor but cannot fully activate it (Chan et al., 1991; Matsumoto and Nakamura, 2003; Mazzone et al., 2004). Similarly, anti-HGF-neutralizing antibodies act by subtracting functional HGF in the microenvironment (Cao et al., 2001), some of which are in pre-clinical or phase II clinical trials (Kim et al., 2006; Jun et al., 2007), whereas decoy Met, a soluble truncated Met extracellular receptor domain, both sequesters the ligand and impairs receptor dimerization (Michieli et al., 2004). The main limit of using HGF inhibitors is that they only inhibit HGF-dependent receptor activation. Few antagonist antireceptor monoclonal antibodies are available; these antibodies tend to have agonistic rather than antagonistic properties due to their bivalent structure (Prat et al., 1998). One promising monoclonal antibody, DN-30, is able to downregulate Met and inhibit tumor growth in experimental models (Vigna et al., 2008). Gene silencing based on antisense, ribozyme and RNA interference techniques have been used experimentally to silence Met and HGF expression (Paranjpe et al., 2007; Corso et al., 2008; Chu et al., 2009).

Finally, peptides interfering with the association of signal transducers to the Met receptor docking site could block the propagation of Met signaling. Previous studies have shown that a peptide derived from the carboxyl-terminal tail of Met specifically inhibited kinase activity and HGF-induced invasive growth in normal and transformed epithelial cells in vitro (Bardelli et al., 1999).

On this basis, we investigated whether synthetic Met peptides could interfere with angiogenesis in vitro and in vivo. The peptide was delivered into cells by fusion with the internalization sequences from either the Antennapedia homeodomain (Antp) or HIV-Tat previously shown to translocate peptides efficiently across the plasma membrane (Deshayes et al., 2005; Gupta et al., 2005; Foged and Nielsen, 2008; Morris et al., 2008; Stewart et al., 2008).

We show that micromolar concentrations of these peptides specifically inhibited HGF-induced in vitro migration, invasion and morphogenesis of endothelial cells, interfering with downstream signaling by HGF. Comparison with the inhibitor PHA-665752 showed that the peptides exerted greater inhibitory effects, yet no toxicity, whereas PHA-665752 showed substantial toxicity. In vivo, the peptides impaired HGF-dependent angiogenesis and significantly inhibited the growth of Kaposi's sarcoma xenograft, as well as vascularization. These data suggest a possible pharmacological mechanism to interfere with Met-mediated angiogenesis.

\section{Results}

\section{Cell internalization of the Met docking site peptide}

The plasma membrane, which limits cell internalization of most proteins and peptides, can be crossed by cellpenetrating peptides, such as Tat and Antp, which can be used to deliver peptides into living cells. We verified efficient peptide internalization by incubating 5-(and-6)carboxyfluorescein (FAM)-conjugated Tat-Met peptide $(10 \mu \mathrm{M})$ with human umbilical vein endothelial cells (HUVEC) and monitoring fluorescence with flow cytofluorimetry. Peptide uptake was time dependent, with more than $50 \%$ of the cells being fluorescent after as little as $10 \mathrm{~min}$ and nearly $100 \%$ after $30 \mathrm{~min}$ (Figure 1). An FAM-conjugated Met peptide lacking the Tat cell-penetrating peptide motif did not cross the cell membrane even after extensive incubation, showing levels of fluorescence similar to those of controluntreated HUVEC.

\section{Met docking site peptides inhibit HUVEC proliferation}

The cell-penetrating Antp-Met and Tat-Met peptides were tested for their ability to interfere with HGFinduced proliferation of HUVEC and compared with PHA-665752. Significant inhibition of cell growth in MTT (3-(4,5-dimethylthiazol-2-yl)-2,5-diphenyltetrazolium bromide) assays was observed at doses of $10 \mu \mathrm{M}$ Antp-Met already after $24 \mathrm{~h}$ of treatment (Figure 2a). Higher concentrations of the Antp-Met completely abolished cell proliferation. Tat-Met and Tat s-Met (containing a shorter Tat peptide), used at $10 \mu \mathrm{M}$ concentrations, showed a significant reduction of cell proliferation only after $48 \mathrm{~h}$ (Figures $2 \mathrm{~b}$ and c). At higher concentrations $(20$ and $50 \mu \mathrm{M})$ they displayed a cytostatic activity starting from $24 \mathrm{~h}$ of incubation. Lower concentrations of peptides $(1 \mu \mathrm{M})$ did not have any effect even in longer treatments.

In contrast, we observed a marked inhibitory effect starting from the 24-h time point when we exposed endothelial cells to micromolar concentrations (5 and $10 \mu \mathrm{M}$ ) of PHA-665752 (Figure 2d). Lower PHA-665752 concentrations did not exert any significant reduction in proliferation with respect to the control.

These data show that the internalized Met peptides inhibited cell proliferation; the Antp-coupled Met peptide appears to have a stronger inhibitory activity, 

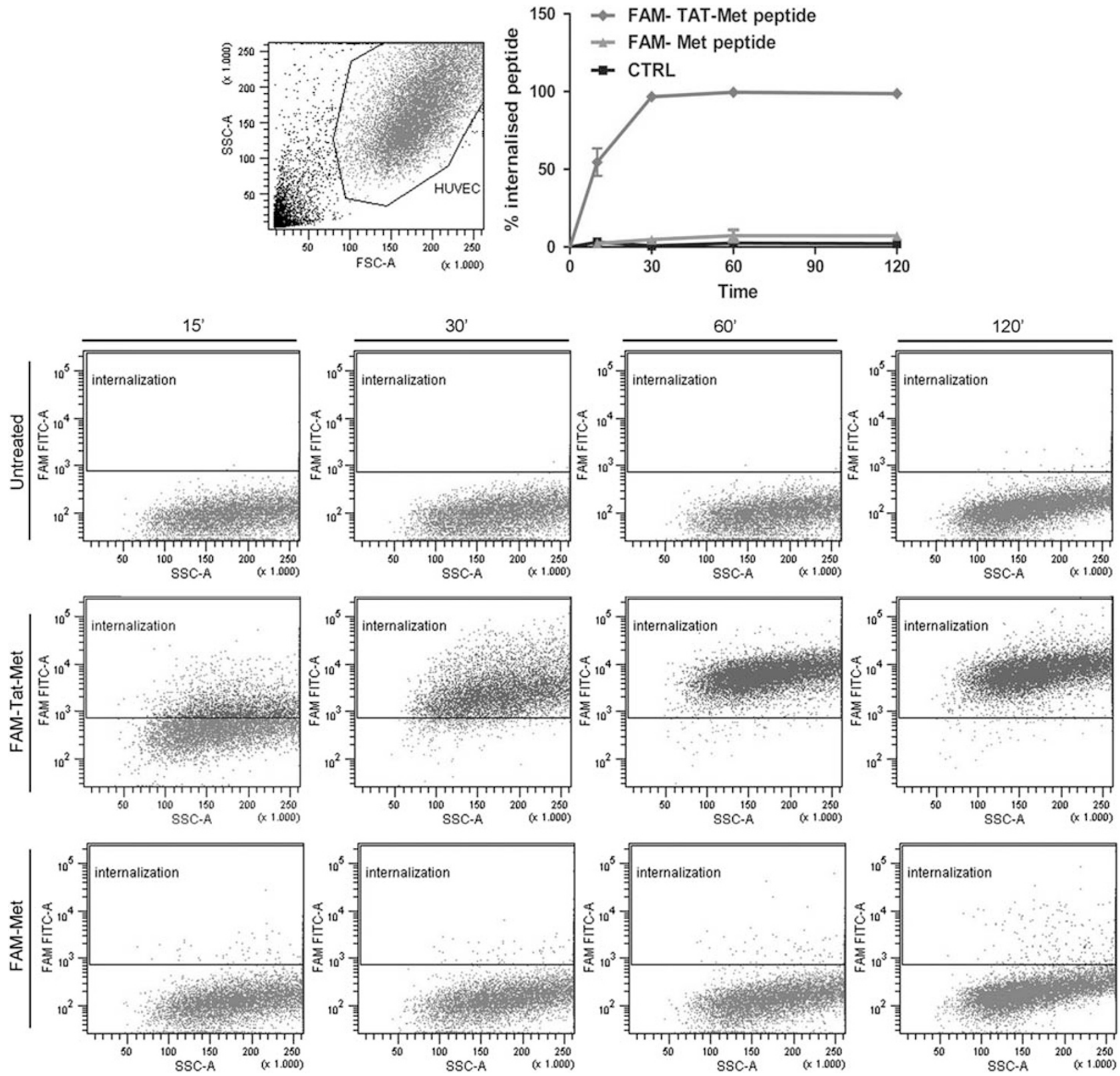

Figure 1 The Tat-Met peptide enters into HUVECs. Tat-Met was conjugated at the N-terminus with FAM. HUVECs $\left(1 \times 10^{5}\right)$ were incubated for different periods of time with $10 \mu \mathrm{m}$ peptide, washed twice and analyzed by fluorescence-activated cell sorting. Labeled Met peptide devoid of the cell-penetrating peptide motif and untreated cells (CTRL) were used as controls. In the lower panels, representative dot plots of peptide internalization percentage are shown.

whereas PHA-665752 required relatively high concentrations to attain comparable effects.

\section{Met docking site peptides do not exert toxicity or induce} apoptosis in endothelial cells

The possibility that the Met inhibitors used could exert toxicity or induce endothelial cell apoptosis was evaluated by cytofluorimetric analysis. After only $2 \mathrm{~h}$ of treatment of endothelial cells in the presence of $\mathrm{HGF}$ with $250 \mathrm{~nm}$ PHA-665752, approximately $60 \%$ of the cells (Figure 3a) were already undergoing apoptosis (both Annexin V and 7-amino-actinomycin D positive). In contrast, cells treated with the peptides, even at highest concentrations, showed a high percentage (about $95 \%$ ) of viable endothelial cells and no apoptosis (Figure 3a). The toxicity of PHA-665752 was observed even in the presence of serum (fetal bovine serum (FBS)) with clear dose-dependent effects (Figure 3b). These data suggest that the growth inhibition exerted by PHA-665752 may be due to cytotoxicity and apoptosis.

The Met docking site peptide specifically inhibits HGF-dependent HUVEC migration and invasion Endothelial cells must cross basement membranes to form new blood vessels during angiogenesis; we investigated whether the peptides could affect 

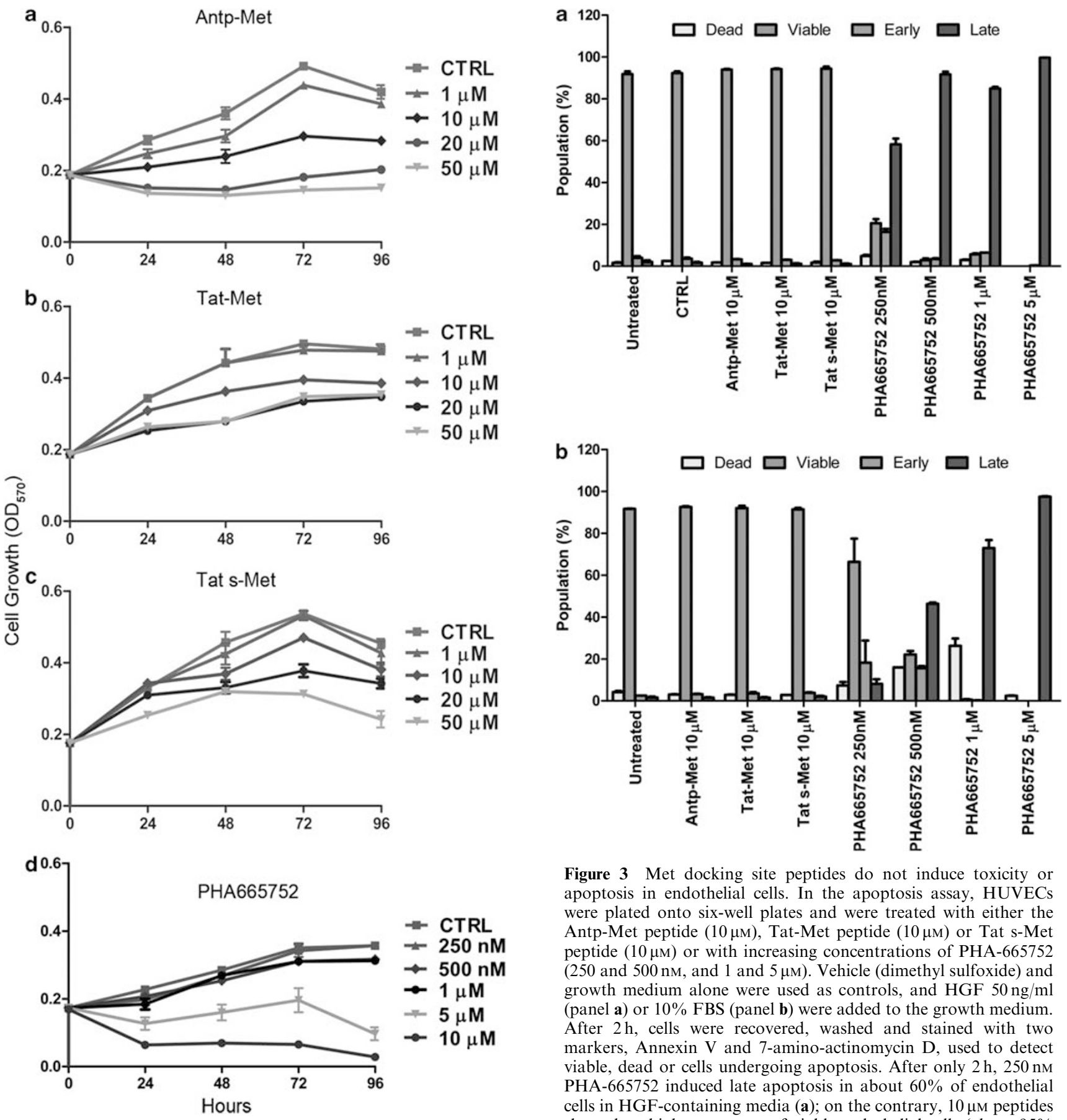

Figure 2 The Met docking site peptide inhibits HUVEC proliferation (MTT (3-(4,5-dimethylthiazol-2-yl)-2,5-diphenyltetrazolium bromide)assay). HUVECs were plated at low density, and then starved in low serum. Cell proliferation was evaluated at fixed times after the addition of HGF $(50 \mathrm{ng} / \mathrm{ml})+/-$ Antp-Met (a), Tat-Met (b), Tat s-Met (c) or PHA-665752 (d) at different concentrations in 2\% FBS-containing medium. The inhibitory effect of Antp-Met $(10 \mu \mathrm{M})$ was already significant after $24 \mathrm{~h}$, whereas the inhibitory effect of Tat-Met or Tat s-Met peptides were significant only after $48 \mathrm{~h}$ and when $20 \mu \mathrm{m}$ concentrations were used. PHA-665752 showed a marked reduction in cell numbers starting from $24 \mathrm{~h}$ at micromolar concentrations $(5$ and $10 \mu \mathrm{M})$, whereas lower concentrations did not exert a significant reduction of proliferation with respect to the control. Means \pm s.e.m. are shown $(P<0.05)$.

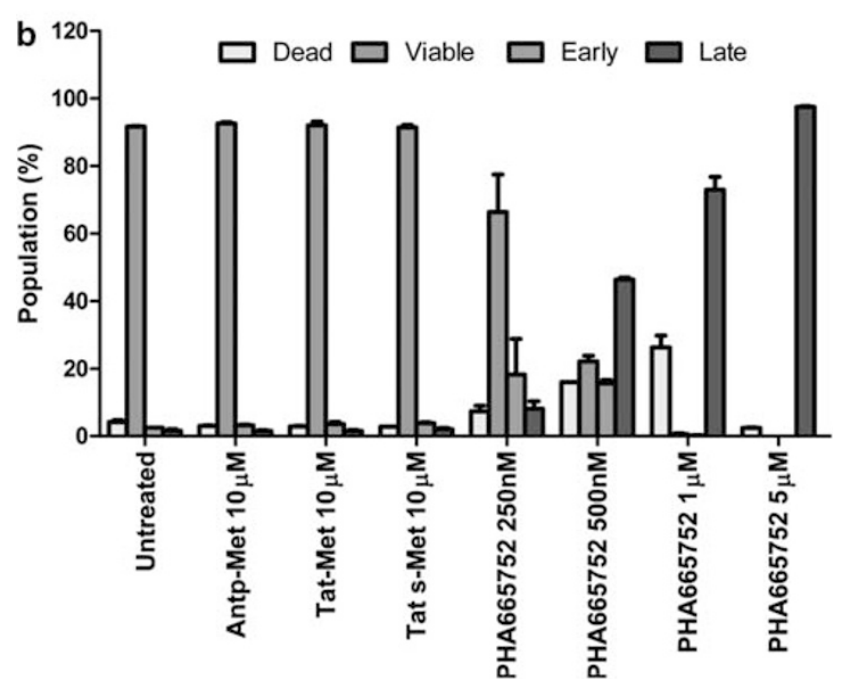

Figure 3 Met docking site peptides do not induce toxicity or apoptosis in endothelial cells. In the apoptosis assay, HUVECs were plated onto six-well plates and were treated with either the Antp-Met peptide $(10 \mu \mathrm{M})$, Tat-Met peptide $(10 \mu \mathrm{m})$ or Tat s-Met peptide $(10 \mu \mathrm{M})$ or with increasing concentrations of PHA-665752 (250 and $500 \mathrm{~nm}$, and 1 and $5 \mu \mathrm{m}$ ). Vehicle (dimethyl sulfoxide) and growth medium alone were used as controls, and HGF $50 \mathrm{ng} / \mathrm{ml}$ (panel a) or $10 \%$ FBS (panel b) were added to the growth medium. After $2 \mathrm{~h}$, cells were recovered, washed and stained with two markers, Annexin V and 7-amino-actinomycin D, used to detect viable, dead or cells undergoing apoptosis. After only $2 \mathrm{~h}, 250 \mathrm{~nm}$ PHA-665752 induced late apoptosis in about $60 \%$ of endothelial cells in HGF-containing media (a); on the contrary, $10 \mu \mathrm{M}$ peptides showed an high percentage of viable endothelial cells (about $95 \%$ of the population; a). The toxicity of PHA-665752 was marked both in the presence of HGF (a) or FBS (b). The experiment was performed three times and each condition was in triplicate.

HGF-dependent HUVEC motility and invasion. Under the effect of HGF $(50 \mathrm{ng} / \mathrm{ml})$, the number of migrated cells in a Boyden chamber assay doubled; a noncytotoxic dose of $10 \mu \mathrm{m}$ peptides abrogated this migration (Figure $4 \mathrm{a} ; * P<0.05$ ). No significant differences in migration-inhibitory activity were found among the different peptides. We observed equivalent inhibitory effects with PHA-6657525 only in the presence of the highest (cytotoxic) concentrations (5 and $10 \mu \mathrm{M}$ ) 

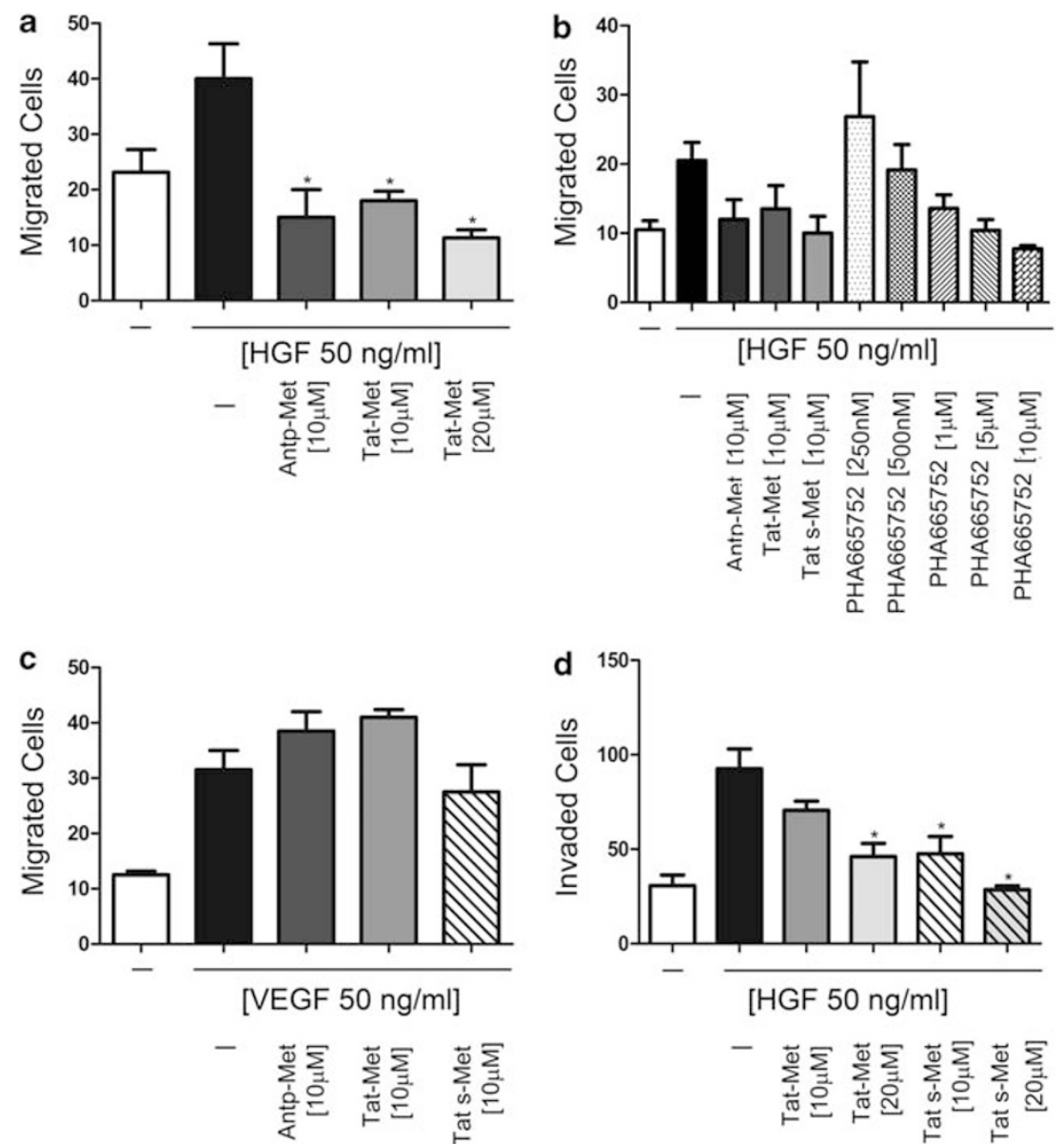

Figure 4 The Met docking site peptide strongly inhibits HGF-dependent HUVEC migration and invasion. In the migration assay, HUVECs were seeded into the upper compartment of Boyden chambers in the presence or absence of Antp-, Tat- and Tat s-Met peptides or PHA-665752, whereas chemoattractants $(50 \mathrm{ng} / \mathrm{ml} \mathrm{HGF} \mathrm{(a)} \mathrm{or} 10 \mathrm{ng} / \mathrm{ml}$ VEGF (c)) were placed in the lower compartment. After $6 \mathrm{~h}$ incubation, cells in the upper side of the filter were removed, and cells that migrated to the lower surface were fixed, stained and counted. Serum-free medium (SFM) was used as negative control. Met mimicking cell-penetrating peptides inhibited HUVEC migration induced by HGF, but not that induced by VEGF. The inhibitor PHA-665752 showed the same inhibitory effect of peptides on HGF-dependent migration only at the highest concentrations (5 and $10 \mu \mathrm{M})$. The invasion assay was performed similarly, except that the filter separating the two compartments was pre-coated with matrigel and incubation was for $18 \mathrm{~h}$. Tat- and Tat s-Met peptides inhibited HGF-induced matrigel invasion in dose-dependent manner (d). All experiments were performed in triplicate and repeated three times. Means \pm s.e.m. are shown $\left({ }^{*} P<0.05\right)$.

(Figure 4b). The Met peptides did not inhibit VEGFdependent cell migration (Figure 4c), thus showing clear specificity.

In an invasion assay performed in Boyden chambers with filters pre-coated with a reconstituted basement membrane (matrigel), treatment with Tat-Met or Tat s-Met significantly reduced the HGF-induced invasion (Figure 4d). Tat s-Met displayed a higher inhibitory activity than Tat-Met $(* P<0.05)$, and in both cases a dose-dependent effect was observed (Figure 4d).

\section{The Met docking site peptide inhibits endothelial morphogenesis in vitro}

Human umbilical vein endothelial cells can organize into capillary-like structures when cultured on a thick matrigel layer in the presence of angiogenic factors. The Met peptides interfered with HGF-induced HUVEC morphogenesis with the same efficacy shown in inhibiting cell proliferation (Supplementary data) Antp-Met was effective at $10 \mu \mathrm{M}$ (Supplementary data), whereas Tat-Met and Tat s-Met were effective at $20 \mu \mathrm{m}$. Antp-Met did not affect FBS-dependent network formation, showing specificity of the inhibitory effect (Supplementary data). PHA-665752 interfered with HGF-dependent tube formation to a similar extent as that of the peptides only at cytotoxic micromolar concentrations (Supplementary data).

\section{The Met docking site peptide inhibits HGF-dependent downstream signaling}

The different biological responses triggered by HGF and mediated by Met depend on efficient downstream signal transduction, which in turn depends on receptor tyrosine phosphorylation. The binding of HGF leads to the activation of the two major signaling pathways, the ERK1/2 and the phosphoinositide 3-kinase 


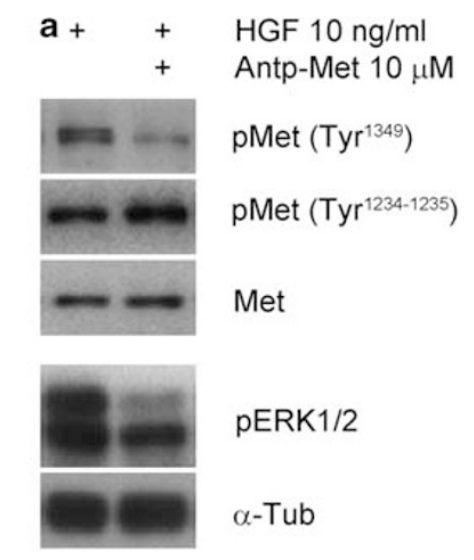

b Huvec 1G11

Figure 5 The Met docking site peptide inhibits the HGFdependent downstream signaling. Quiescent HUVECs were pretreated or not for $2 \mathrm{~h}$ with Antp-Met before stimulation with $10 \mathrm{ng}$ / $\mathrm{ml} \mathrm{HGF}$ for $15 \mathrm{~min}$, and then lysed and processed for Western blot analysis. Blots were probed with anti-phospho Met (tyrosine 1349), anti-phospho Met (tyrosines 1234-1235), anti-phospho ERK1/2, anti-Met and anti- $\alpha$-tubulin. Antp-Met inhibited the phosphorylation of tyrosine 1349, but not of tyrosines 1234-1235. Besides, the phosphorylation of ERK1/2 was impaired by Antp-Met (a). (b) Human and murine endothelial cell lines, HUVEC and 1G11, respectively, express Met receptor protein.

(Birchmeier et al., 2003; Boccaccio and Comoglio, 2006). We tested whether Antp-Met impaired Met receptor phosphorylation in the catalytic loop and in the docking site. Although phosphorylation on tyrosines 1234-1235, localized in catalytic loop, was not affected, phosphorylation on tyrosine 1349 , localized in the carboxylterminal docking site, showed a $70 \%$ reduction when Antp-Met was added to cells $2 \mathrm{~h}$ before stimulation with $10 \mathrm{ng} / \mathrm{ml}$ HGF (Figure 5a). Phosphorylation of ERK1/2, which is mainly involved in transducing proliferation and motility responses (Prat et al., 1998; Birchmeier et al., 2003), was also impaired by the AntpMet peptide (Figure 5a). Taken together, these data show that Met-derived peptides inhibit the phosphorylation of the tyrosines located in this motif, and block activation of the downstream signaling, but do not affect phosphorylation of the tyrosines located in the activation loop.

The Met docking site peptide inhibits in vivo angiogenesis We assessed the effect of the Met peptides on in vivo angiogenesis using a rapid and quantitative matrigel sponge assay. A cocktail of HGF $(50 \mathrm{ng} / \mathrm{ml})$ and heparin $(50 \mathrm{U} / \mathrm{ml})$ promoted a hemorrhagic vascularization of the matrigel sponge, which was clearly detectable at 4 days post-implantation (Figure 6a). Addition of the different Met-derived peptides $(10 \mu \mathrm{M})$ significantly inhibited the HGF-induced angiogenic response, as detected by visual inspection of the pellets and measured in a hemoglobin quantification assay $(* * * P<0.001)$ (Figure 6b). The inhibition was specific, as shown by the lack of effect on the angiogenic response of an AntpMet peptide whose sequence had been scrambled (Figure 6b). Hematoxylin- and eosin-stained sections of pellets showed that the extensive vascularized areas in mice treated with HGF and heparin were substantially reduced in mice treated with the Met peptides $(10 \mu \mathrm{M})$ (Figures 6Ca, b, c).

Immunohistochemistry showed that $\mathrm{CD} 11 \mathrm{~b} / \mathrm{c}$-positive cells were readily detected within pellets containing HGF and heparin, indicating the presence of an inflammatory response; this infiltrate was significantly reduced when Met peptides were co-injected in matrigel (Figures $6 \mathrm{Ca}^{\prime}, \mathrm{b}^{\prime}, \mathrm{c}^{\prime}$ ).

The Met docking site peptide inhibits the growth and vascularization of Kaposi's sarcomas in nude mice

We next examined whether the peptides were able to effect growth and vascularization of tumors in vivo. KSImm Kaposi's sarcoma cells were injected in liquid matrigel with or without Tat s-Met $(10 \mu \mathrm{M})$, followed by treatment with peptides subcutaneously every second day until termination of the experiment. Treatment with the Tat s-Met peptide clearly inhibited tumor growth (Figure 7a). Hematoxylin-eosin staining of sections of tumors showed extensive areas of vascularization in control tumors, whereas extensive necrotic areas and strongly reduced vascularization were found in tumors of animals receiving peptides (Figures 7Ba, b). Immunohistochemical staining indicated that in peptide-treated tumors $\mathrm{CD} 11 \mathrm{~b} / \mathrm{c}$-positive inflammatory cells were significantly reduced (Figures $7 \mathrm{Ba}^{\prime}, \mathrm{b}^{\prime}$ ). To confirm the reduction of vascularization in tumors treated with peptide, we performed an immunofluorescence analysis for the endothelial marker von Willebrand (Figures $\left.7 \mathrm{Cb}, \mathrm{b}^{\prime}\right)$ and we observed a higher number of von Willebrand-positive cells (Figure 7Cb) in control tumors than in tumors treated with Tat s-Met (Figure $\left.7 \mathrm{Cb}^{\prime}\right)$. We observed colocalization of the Met receptor and the von Willibrand endothelial marker in the tumors (Figures $7 \mathrm{Cc}, \mathrm{c}^{\prime}$ ), suggesting that murine tumor endothelial cells express Met. This was consistent with the presence of Met (Figure 5b) in the 1G11 murine lung microvascular endothelial cell line (Dong et al., 1997).

In another set of experiments, Antp-Met, or a scrambled peptide (both at $10 \mu \mathrm{M}$ ), was injected in the peri-tumor area every second day after the tumor was established. Again, the peptide significantly inhibited tumor growth, whereras the scrambled peptide had no effect on tumor growth (Figure 7D). The central necrotic areas (Figures 7Ea, b) and the strong inflammatory infiltrate (Figures $7 \mathrm{Ea}^{\prime}, \mathrm{b}^{\prime}$ ) again were strongly reduced in the presence of the Met peptide as compared with controls receiving either vehicle alone or scrambled peptide. These data indicate that the Met peptides, while not toxic for healthy endothelial cells, strongly and specifically inhibited tumor angiogenesis, inflammation and growth. 


\section{Discussion}

Angiogenesis is associated with several pathologies, including chronic inflammation and arthritis, atherosclerosis, macular degeneration and cancer (Carmeliet

A
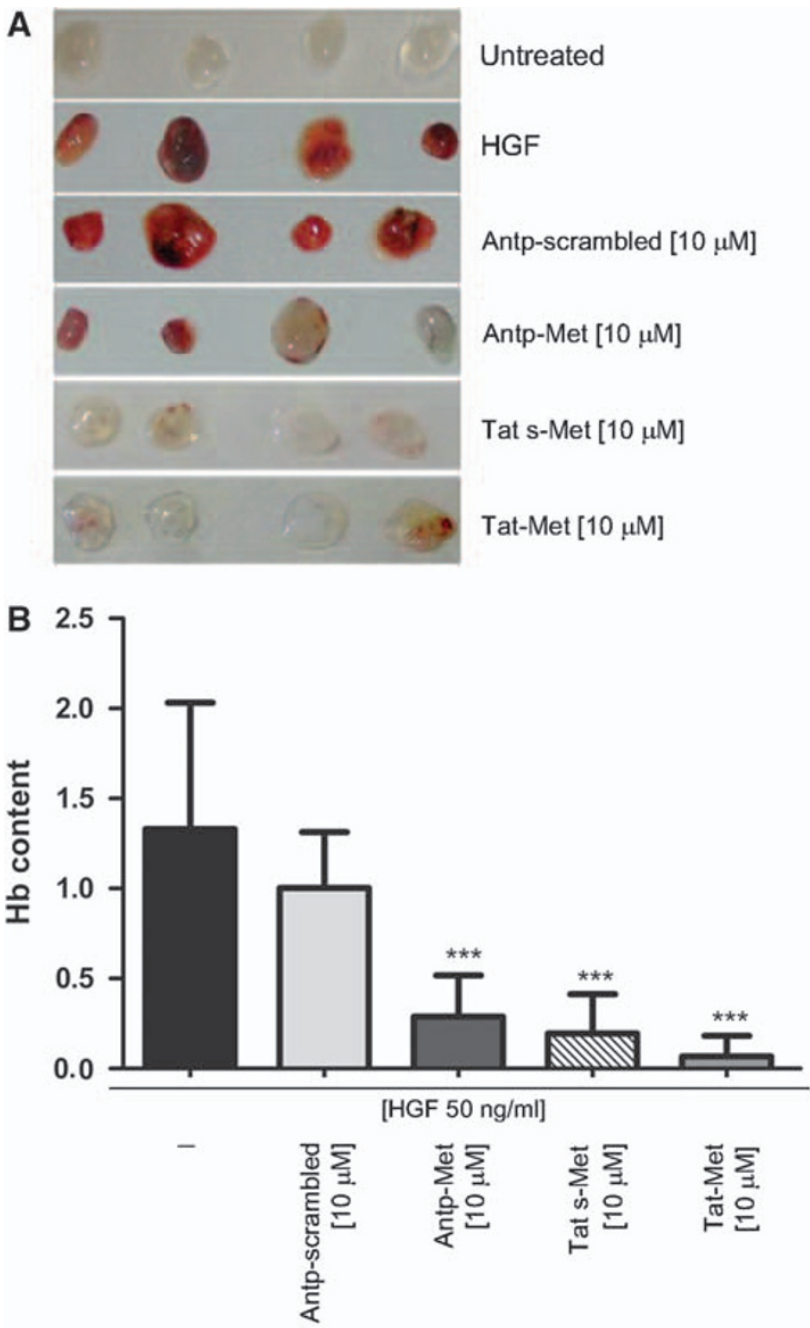

C

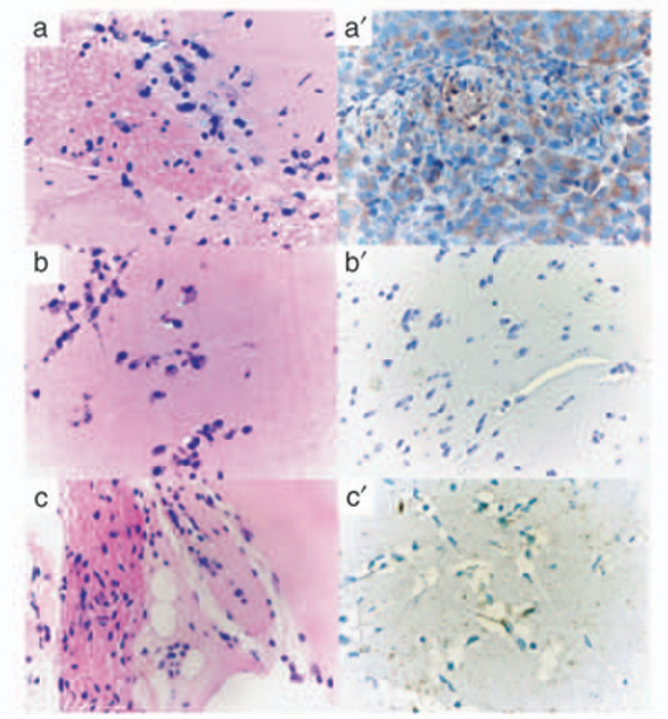

and Jain, 2000); therapeutic strategies have envisioned angiogenesis as a promising target (Folkman, 1985; Carmeliet and Jain, 2000; Ferrara, 2004; Goh et al., 2007). HGF and its receptor Met are able to stimulate endothelial cell migration, proliferation and organization into capillary-like tubes and angiogenesis (Bussolino et al., 1992; Grant et al., 1993; Silvagno et al., 1995). HGF can induce pro-angiogenic cytokine expression, directly activating angiogenic pathways (Dong et al., 2001; Sengupta et al., 2003) or downregulating the expression of angiogenic inhibitors (Zhang et al., 2003) and promoting lymphangiogenesis (Cao et al., 2006). The HGF/Met axis has been proposed as a target for antiangiogenic therapy (You and McDonald, 2008).

Structural and functional integrity of endothelial cells is a fundamental factor for vessel homeostasis and function. Alterations in the endothelium are associated with increased risk for several diseases, including cardiovascular diseases and adverse events. Agents affecting endothelial integrity, inducing apoptosis or direct toxicity, are likely to induce vascular dysfunction. Several small-molecule drugs targeting Met and other kinases show toxicity; biological molecules could be used to obtain higher levels of specificity and lower toxicity in Met inhibition.

Here we describe the antiangiogenic properties of synthetic cell-permeable peptides containing the carboxylterminal tail of Met in the absence of cytotoxicity or apoptosis induction. These peptides inhibit HGF-induced proliferation, migration, invasiveness and capillary-like network formation in endothelial cells in vitro. Comparison of our peptides with the ATP-competitive inhibitor PHA665752 showed that similar inhibitory effects were obtained only at high concentrations of PHA-665752 that were associated with apoptosis and toxicity. The ability of these peptides to interfere with pathological responses with no cytotoxic effects would be of clinical relevance to minimize the additive toxicity phenomena due to the administration of multiple inhibitor drugs.

The Met docking site peptides were active in vivo, blocking HGF-induced angiogenesis and restraining growth and vascularization of xenografted tumors; this is the first report of the in vivo inhibiting activity of a Met-specific cell-penetrating peptide. Homozygous genetic deletion of either Met or HGF is lethal in utero due to defects in placental development (Bladt et al., 1995; Schmidt et al., 1995; Uehara et al., 1995). However, the Met-/- mice did not show an endothelial phenotype

Figure 6 The Met docking site peptide inhibits in vivo angiogenesis. A cocktail of $\mathrm{HGF}(50 \mathrm{ng} / \mathrm{ml})$ and heparin $(50 \mathrm{U} / \mathrm{ml})$ promoted a hemorrhagic vascularization of the matrigel sponge clearly detectable at 4 days post-implantation. HGF-induced vascularization of the subcutaneously injected matrigel implants was significantly inhibited by the addition of micromolar concentration of Met peptides, as detectable at visual inspection (A) and quantified by measuring hemoglobin $(\mathrm{Hb})$ content of the pellets $(\mathbf{B})$ $(* * * P<0.001)$. Representative histological specimens that were stained with hematoxylin and eosin show extensive necrotic areas $(\mathbf{C}(\mathrm{a}, \mathrm{b}$ and $\mathrm{c}))$. CD11b/c immunohistochemistry on adjacent sections show abrogation/impairment of cellular infiltrates in the pellets treated with the peptides $\left(\mathbf{C}\left(\mathrm{a}^{\prime}, \mathrm{b}^{\prime}\right.\right.$ and $\left.\left.\mathrm{c}^{\prime}\right)\right)(\times 400$ magnification). 
(Bladt et al., 1995) and the morphological appearance of endothelium in $\mathrm{HGF}-/$ - embryos was not altered (Uehara et al., 1995). These data suggest that the Met/ HGF axis may have a major role in pathological but not in physiological angiogenesis, as proposed for other angiogenic factors such as PIGF (Fischer et al., 2008). This would be consistent with the role of Met in endothelial cells (Figure 6b), the co-expression with the endothelial marker in vivo (Figure $7 \mathrm{~b}$ ) and the lack of toxicity in vitro and in vivo.

Biochemically, the peptides strongly impaired HGFdependent activation of the Ras-MAPK ERK1/2 transduction pathway (Ponzetto et al., 1994; Birchmeier et al., 2003), consistent with previous in vitro studies in epithelial cells (Bardelli et al., 1999). The Met-specific peptides were delivered into cells by fusion with the internalization sequences from the Antp homeodomain 3 or the HIV-Tat basic domain, which proved to act efficiently as transporters across membranes (Deshayes et al., 2005; Gupta et al., 2005; Foged and Nielsen, 2008; Morris et al., 2008; Stewart et al., 2008). A similar peptide fused to the Tat internalizing sequence enhanced in vitro chemosensitivity of glioma cells to a cis-platinum derivative (Lou et al., 2009). The three peptides containing the Met docking site coupled to different internalizing sequences showed only small differences in their inhibitory efficiency in vitro and in vivo. The three peptides displayed clear specificity for Met receptor; they did not impair VEGF- or FBS-induced effects on endothelial cells in vitro and a scrambled peptide was ineffective in vivo.

The Met-specific peptide inhibited the phosphorylation of $Y^{1349}$, which binds the $\mathrm{p} 85$ regulatory subunit of phosphoinositide 3-kinase (Graziani et al., 1991; Ponzetto et al., 1994; Bardelli et al., 1999; Lou et al., 2009), mainly involved in transducing HGF-dependent motogenic and antiapoptotic responses (Ponzetto et al., 1993; Khwaja et al., 1998; Giordano et al., 2000; Deregibus et al., 2003). Phosphorylation of the MAPK ERK $1 / 2$, whose activation is required for the proliferative and invasive responses (Ponzetto et al., 1994; Prat et al., 1998; Birchmeier et al., 2003; Bardelli et al., 2005), was impaired. Although strongly interfering with the activation of the tyrosines located in the docking site, the peptide had no effect on phosphorylation of $\mathrm{Y}^{1234}, \mathrm{Y}^{1235}$, localized in the activation loop, as it appears to compete with substrate access to the catalytic pocket (Bardelli et al., 1999).

Current clinical approaches to targeting angiogenesis have focused on blocking VEGF signaling by either anti-VEGF antibodies or multitargeted receptor tyrosine kinase inhibitors (Folkman, 1985; Carmeliet and Jain, 2000; Ferrara, 2004; Goh et al., 2007; Loges et al., 2009). Current clinical experience has revealed that VEGF-targeted therapy prolongs overall survival of cancer patients by only months, and experimental models have recently shown that anti-VEGF treatment inhibits primary tumor growth, but may promote invasiveness and metastasis (Pennacchietti et al., 2003; Ebos et al., 2009; Paez-Ribes et al., 2009). The fact that Met is both a pro-angiogenic factor and an oncogene suggested that it may be an optimal target for anticancer treatment, simultaneously inhibiting angiogenesis and oncogenesis (Michieli et al., 2004) and potentially complementing VEGF targeted antiangiogenic therapy.

Our observations provide the novel result that Metspecific peptides mimicking the tail multifunctional docking site can block angiogenesis and consequent cancer growth and related metastatic dissemination.

\section{Materials and methods}

\section{Reagents}

Murine recombinant VEGF-A, human recombinant VEGFA165, murine recombinant tumor necrosis factor- $\alpha$ and human recombinant $\mathrm{HGF}$ in its biologically active form (Gherardi et al., 2006) were purchased from Peprotech (Offenbach, Germany); heparin was obtained from Sigma (Sigma-Aldrich Chemie, Taufkirchen, Germany). Matrigel was prepared from the Engelbreth-Holm-Swarm sarcoma as described previously (Kleinman et al., 1986).

Cell-permeable peptides containing the Met docking site sequence (ref. seq: NP_000236), or a control scrambled sequence, fused to the internalization sequences of either the homeodomain 3 of the Antennapedia protein (ref. seq: NP_996167) or the Tat transactivator domain (ref. seq: NP 057853) at their N-terminus were synthesized and purified by Primm (Milan, Italy). Two Tat sequences of different lengths were used. Peptides conjugated to FAM at their $\mathrm{N}$-terminus were used to evaluate internalization. Peptide sequences are reported in Table 1.

\section{Cell cultures}

Human umbilical vein endothelial cells were purchased from Promo Cell (Heidelberg, Germany) and grown on 1\% gelatincoated tissue culture plates in M199 endothelial growth medium (Sigma, St Louis, MO, USA), supplemented with $10 \%$ heat-inactivated FBS, $1 \%$ L-glutamine, fibroblast growth factors $(1 \mu \mathrm{g}$ acid-fibroblast growth factor plus $1 \mu \mathrm{g}$ basicfibroblast growth factor $/ 100 \mathrm{ml}$ ), epidermal growth factor $(1 \mu \mathrm{g} / 100 \mathrm{ml})$, heparin $(10 \mathrm{mg} / 100 \mathrm{ml})$ and hydrocortisone $(0.1 \mathrm{mg} / 100 \mathrm{ml})$. Cells were used between the second and eighth passage in vitro. The murine lung endothelial cell line (1G11) was the kind gift from Annunciata Vecchi (Istituto Clinico Humanitas, IRCCS and University of Milan, Milan, Italy).

\section{Cytofluorimetric analysis}

Human umbilical vein endothelial cells $\left(6 \times 10^{5}\right)$ were incubated with $10 \mu \mathrm{M}$ concentrations of FAM-labeled peptides for different periods of time (10,30,60 and $120 \mathrm{~min})$. Cells were then recovered, washed twice with phosphate-buffered saline (PBS), fixed in 4\% paraformaldehyde and analyzed by flow fluorocytometry in a FACSCanto (BD Biosciences, San Jose, CA, USA).

To compare the effect of our peptides with that of the Metspecific inhibitor PHA-665752 (the kind gift of Professor Livio Trusolino, Univ. Torino), $1 \times 10^{5}$ HUVECs were plated onto six-well plates and allowed to adhere overnight. The next day, the cells were treated in the growth medium (in the presence of HGF $50 \mathrm{ng} / \mathrm{ml}$ or $10 \%$ FBS) with the Antp-Met peptide $(10 \mu \mathrm{M})$, Tat-Met peptide $(10 \mu \mathrm{M})$ or Tat s-Met peptide $(10 \mu \mathrm{M})$ or with increasing concentrations of PHA-665752 (250 and $500 \mathrm{~nm}$, and 1 and $5 \mu \mathrm{M})$. Dimethyl sulfoxide and growth medium alone (in the presence of HGF $50 \mathrm{ng} / \mathrm{ml}$ or $10 \% \mathrm{FBS}$ ) 
were used as controls. After $2 \mathrm{~h}$, cells were recovered, washed with PBS and transferred to test tubes. Cells were pelleted and resuspended in Annexin V-binding buffer (0.01 M HEPES (4-(2-hydroxyethyl)-1-piperazineethanesulfonic acid) ( $\mathrm{pH} 7.4)$;
$0.14 \mathrm{M} \mathrm{NaCl} ; 2.5 \mathrm{~mm} \mathrm{CaCl}_{2}$ ). Fluorescein isothiocyanate Annexin V and 7-amino-actinomycin D (BD Biosciences) were added to each test tube and incubated for $15 \mathrm{~min}$ at room temperature in the dark. Cells were then washed in PBS,
A
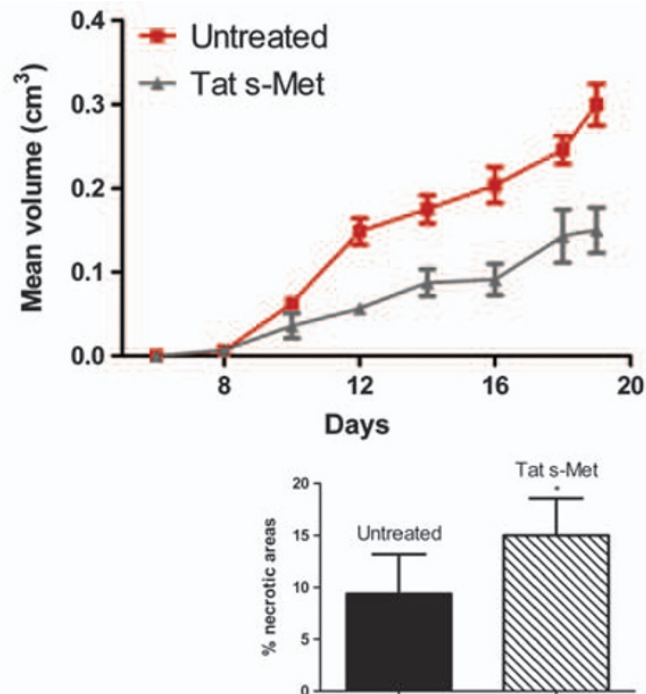

B

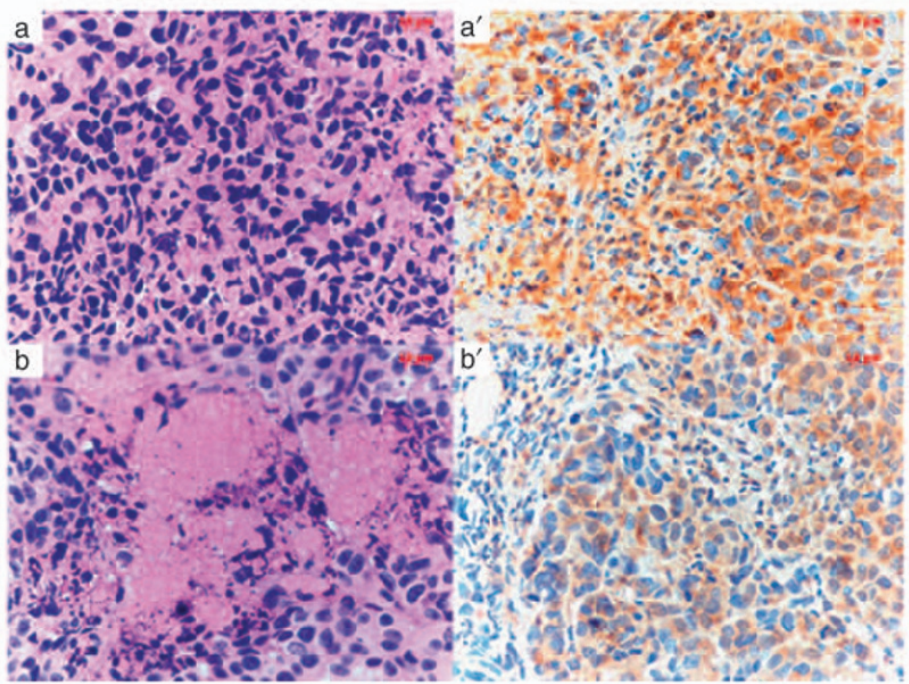

C

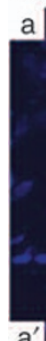

$a^{\prime}$ b

$b^{\prime}$ $c$

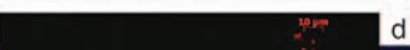

d

$d^{\prime}$
D
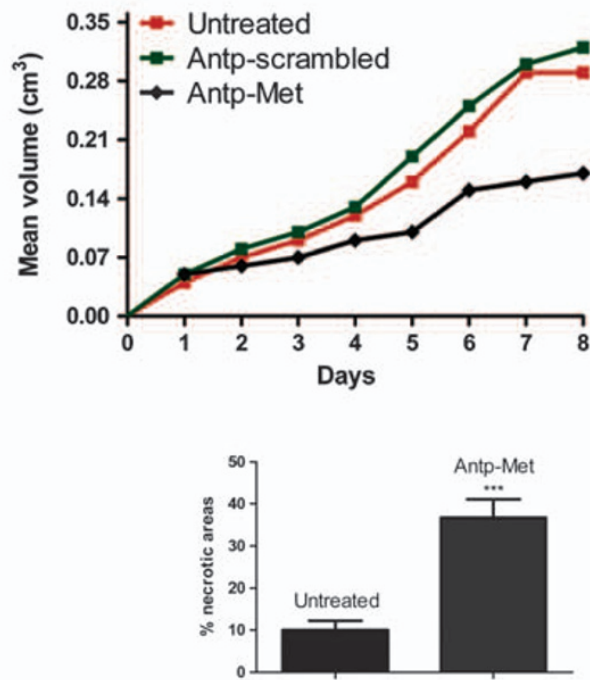

E

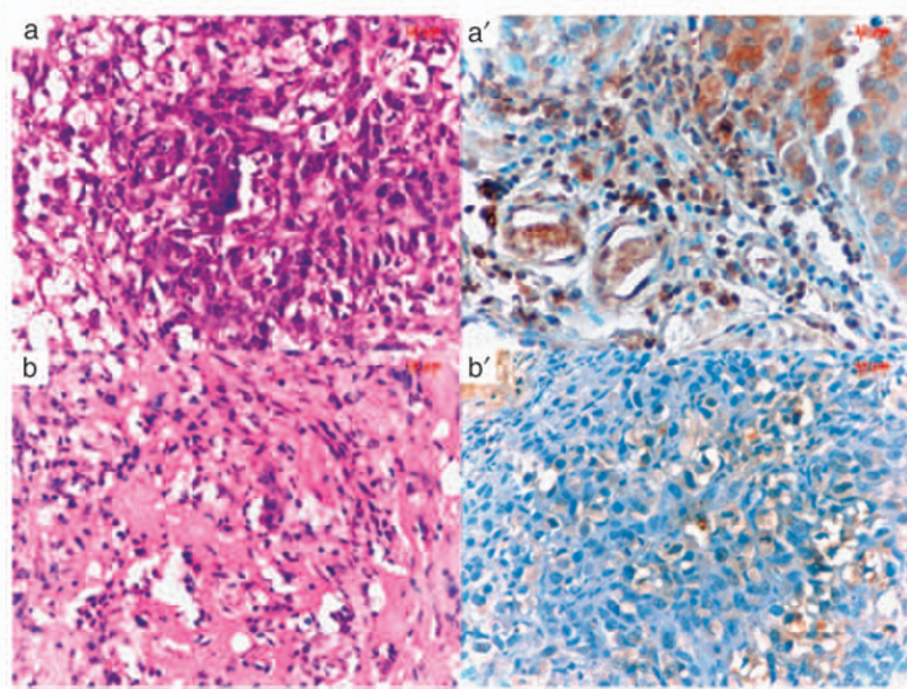


supernatants discarded and resuspended in $400 \mu \mathrm{l}$ of binding buffer. Samples were acquired by flow fluorocytometry using a FACSCanto (BD Biosciences) and analyzed using FACSDiva Software 6.1.2. The experiment was performed three times and each condition was a triplicate.

\section{In vitro cell viability}

Human umbilical vein endothelial cell viability was evaluated in the MTT assay. Cells (1000/well) were seeded into 96multiwell plates in complete medium and, after complete adhesion, the medium was replaced with $2 \%$ FBS fresh medium with or without $50 \mathrm{ng} / \mathrm{ml} \mathrm{HGF}$ and/or different peptides at different concentrations $(1-50 \mu \mathrm{M})$ or with or without PHA-665752 at increasing concentrations $(250 \mathrm{nM}-10 \mu \mathrm{M})$. After different periods of incubation (24, 48, 72 and 96h), plates were processed and absorbance read at $570 \mathrm{~nm}$.

\section{Migration, invasion and morphogenesis assays}

These assays were performed in modified Boyden chambers, as described previously (Albini et al., 1987; Albini and Benelli, 2007). HUVECs $\left(5 \times 10^{4}\right)$ were washed with PBS, resuspended in serum-free medium and placed in the upper compartment. Chemoattractants $(50 \mathrm{ng} / \mathrm{ml} \mathrm{HGF}$ or $10 \mathrm{ng} / \mathrm{ml} \mathrm{VEGF})$ in serum-free M199 medium were added in the lower compartment and the different peptides or PHA-665752 at different concentrations added. Pore-size polycarbonate filters $(12 \mu \mathrm{M})$ were pre-coated with collagen $(50 \mu \mathrm{g} / \mathrm{ml})$ or matrigel $(1 \mathrm{mg} / \mathrm{ml})$. After $6 \mathrm{~h}$ (migration) or overnight (invasion) incubation, the filters were recovered, cells on the upper surface mechanically removed and cells migrated to or invaded the lower filter surface fixed with absolute ethanol and stained with toluidine blue. Cells were counted in a double-blind manner in eight consecutive fields each with a light microscope. All experi-

Table 1 Peptide sequences

\begin{tabular}{ll}
\hline Antp-Met & RQIKIWFQNRRMKWKK IGEHYVHVNATYVNV \\
& KCVA \\
Tat-Met & GRKKRRQRRRPP IGEHYVHVNATYVNVKCVA \\
Tat s-Met & RKKRRQRRR IGEHYVHVNATYVNVKCVA \\
Antp- & RQIKIWFQNRRMKWKK IVAVNCGV- \\
scrambled & HYEHTNVKVYA \\
Met & IGEHYVHVNATYVNVKCVA \\
\hline
\end{tabular}

Cell-permeable peptides derived from the Met receptor docking site fused to internalization sequences from the Antennapedia and Tat proteins. Met sequence alone was used as control of cell internalization. ments were performed three times in triplicate. The in vitro morphogenesis assay was performed as described by Grant et al. (1989) in the presence of $50 \mathrm{ng} / \mathrm{ml} \mathrm{HGF}$ or $10 \% \mathrm{FBS}$, and with the peptides or PHA-665752 in increasing concentrations. After $6 \mathrm{~h}$ incubation on matrigel, the dimensional organization of the cells was examined under an inverted microscope (Zeiss, Oberkochen, Germany), equipped with CCD optics and a digital analysis system.

\section{Western blotting}

Human umbilical vein endothelial cells, pre-incubated in serum-free medium for $24 \mathrm{~h}$, were pre-treated for $2 \mathrm{~h}$ with $10 \mu \mathrm{M}$ Antp-Met peptide before stimulation with $10 \mathrm{ng} / \mathrm{ml}$ HGF for $15 \mathrm{~min}$ (Prat et al., 1998). Lysates were prepared using Cell Lysis Buffer (Cell Signaling Technology, Beverly, MA, USA) and protein concentrations evaluated by the DC Protein Assay (Bio-Rad, Hercules, CA, USA). Proteins were separated on $8 \%$ SDS-polyacrylamide gel electrophoresis under reducing conditions and transferred onto polyvinylidene fluoride membranes (Amersham, Biosciences, Otelfingen, $\mathrm{CH}$, USA), which were then incubated with the antibodies directed against the following human antigens: phospho-ERK1/2, tubulin, phospho-Met (tyrosine 1349), phospho-Met (tyrosines 1234-1235) (Cell Signaling Technology) and Met (Santa Cruz Biotechnology Inc, Santa Cruz, CA, USA) diluted in 5\% bovine serum albumin-Tris-buffered saline- $0.1 \%$ Tween. Horseradish-peroxidase-conjugated secondary antibodies against rabbit or anti-mouse immunoglobulin (Cell Signaling Technology; 1:5000) were then used and reactions were visualized with the enhanced chemiluminescence kit (ECL) from Amersham Biosciences (Pittsburg, PA, USA). Lysates, HUVEC and 1 G11 cells, were incubated with antibodies directed against human Met and mouse Met (both provided by Santa Cruz Biotechnology Inc), respectively.

\section{In vivo matrigel sponge assay}

The assay was performed as described (Albini et al., 1994). $\mathrm{HGF}(50 \mathrm{ng} / \mathrm{ml}$ in the presence of heparin $50 \mathrm{U} / \mathrm{ml})$, with or without peptides, was added to unpolymerized liquid matrigel and slowly injected subcutaneously into the flanks of 6- to 8-week-old C57/BL6 male mice (Charles River Laboratories, Calco (Lecco), Italy) in groups of 4-8 mice for each treatment. Four days after injection, the animals were killed and the pellets were removed, weighed, and either formalin-fixed and paraffin-embedded for histological examination, or minced and diluted in water for hemoglobin content measurement with a Drabkin reagent kit (Sigma). The final hemoglobin

Figure 7 The Met docking site peptide impairs the growth and vascularization of established Kaposi's sarcomas in nude mice. Mice with xenografted Kaposi's sarcoma tumors (either established (D, E) or not $(\mathbf{A}, \mathbf{B})$ ) were injected peri-tumorally with equimolar concentrations of either Antp-Met, Tat s-Met or Antp-scrambled (150 $\mu$ l final volume of a $10 \mu \mathrm{M}$ solution) or vehicle alone (control) every second day, as indicated. (A) Tumor growth analysis showed a significant inhibition of tumor growth by Tat s-Met. The inset shows a quantitative analysis of the areas necrosis (as a percentage) in control and Tat s-Met-treated tumors (mean \pm s.e.; ${ }^{*} P<0.001$ ). (B) Hematoxylin and eosin staining of the Kaposi's sarcoma xenografts grown in mice treated with Tat s-Met (b) showed extensive necrotic areas, when compared with tumors from control mice receiving only vehicle (a). Immunostaining of adjacent sections with $\mathrm{CD} 11 \mathrm{~b} / \mathrm{c}$, a marker of inflammatory infiltrates, showed that Tat s-Met treatment strongly inhibited the inflammation associated with the tumor $\left(b^{\prime}\right)$, relative to treatment with vehicle alone (control) $\left(a^{\prime}\right)$. (C) Immunofluorescence staining of Kaposi's sarcoma xenograft sections for the endothelial marker von Willibrand $\left(b\right.$ and $\left.b^{\prime}\right)$ and Met receptor $\left(c\right.$ and $\left.c^{\prime}\right)$. The number of positive von Willibrand cells in control tumors (b) was much higher than that in xenografts treated with Tat-s $\left(b^{\prime}\right)$. The effect of the peptide on vascularization was Met-related, as showed by the colocalization of the Met receptor with the von Willibrand endothelial cell marker in the tumors (c and $\left.\mathrm{c}^{\prime}\right)$. (D) Antp-Met peptide was also able to significantly inhibit tumor growth in vivo. In contrast, a scrambled control peptide had no effect on tumor growth, showing the role of specific Met inhibition. The inset shows a quantitative analysis of the areas necrosis (as a percentage) in control and Antp-Met-treated tumors (mean \pm s.e.; ***P<0.001). (E) Hematoxylin and eosin staining of the Kaposi's sarcoma xenografts grown in mice treated with Antp-Met (b) showed extensive necrotic areas, as compared with tumors from control mice receiving only vehicle (a). CD11b/c immunostaining of adjacent sections also showed a strong Antp-Met inhibition of tumorassociated inflammation $\left(b^{\prime}\right)$ as compared with controls $\left(a^{\prime}\right)(\times 400$ magnification $)$. 
concentration was calculated from a standard calibration curve, after spectrophotometric analysis at $540 \mathrm{~nm}$.

In vivo xenograft tumor growth

Xenografted tumors were obtained by subcutaneous injection of $5 \times 10^{6}$ human KS-Imm cells/mouse, and mixed with liquid matrigel into the flanks of seven-week-old male nude $n u / n u$ (CD-1) BR mice (Charles River Laboratories) as described previously (Albini et al., 1997, 2001). Tat s-Met peptide was injected with cells $(300 \mu \mathrm{l}$ final volume of $10 \mu \mathrm{M}$ peptide corresponding to $34 \mu \mathrm{g} / \mathrm{ml}$ ) and then every second day by peri-tumor injection, whereas control animals received vehicle alone. In another experiment, the Antp-Met peptide $(300 \mu 1$ final volume of $10 \mu \mathrm{m}$ peptide corresponding to $43 \mu \mathrm{g} / \mathrm{ml}$ ) was injected after the tumors had become established. Animals were weighed and tumor growth monitored at regular intervals by measuring the two tumor diameters with a caliper. After the animal was killed, tumors were removed, weighed and processed for histological examination. All procedures were performed in adherence with the ECC Directive for Care and Italian Laws on animal experimentation (Law by Decree 116/92).

\section{Histological analysis}

Sections of $3 \mu \mathrm{M}$ thickness were stained with hematoxylineosin for histological examination. For immunohistochemistry, slides were deparaffinized in xylene, rehydrated and antigens retrieved in EDTA $(\mathrm{pH} 8)$; thereafter, the sections were treated with $3 \%$ of hydrogen peroxide, incubated with rabbit polyclonal CD11b/c antibody (1:600) (ABR, Golden, CO, USA) and peroxidase-coupled anti-rabbit immunoglobulin secondary antibodies, followed by reaction with $3,3^{\prime}$ diaminobenzidine (Dako REAL EnVision system, Peroxidase/ diaminobenzidine +, Dako, Glostrup, Denmark) and finally counterstained with Mayer's hematoxylin (Sigma).

For immunofluorescence microscopy, primary antibodies against von-Willibrand factor (rabbit anti-mouse, 1:100)

\section{References}

Albini A, Benelli R. (2007). The chemoinvasion assay: a method to assess tumor and endothelial cell invasion and its modulation. Nat Protocol 2: 504-511.

Albini A, Fontanini G, Masiello L, Tacchetti C, Bigini D, Luzzi P et al. (1994). Angiogenic potential in vivo by Kaposi's sarcoma cell-free supernatants and HIV-1 tat product: inhibition of KS-like lesions by tissue inhibitor of metalloproteinase-2. AIDS 8: 1237-1244.

Albini A, Iwamoto Y, Kleinman HK, Martin GR, Aaronson SA, Kozlowski JM et al. (1987). A rapid in vitro assay for quantitating the invasive potential of tumor cells. Cancer Res 47: 3239-3245.

Albini A, Morini M, D'Agostini F, Ferrari N, Campelli F, Arena G et al. (2001). Inhibition of angiogenesis-driven Kaposi's sarcoma tumor growth in nude mice by oral $N$-acetylcysteine. Cancer Res 61: 8171-8178.

Albini A, Paglieri I, Orengo G, Carlone S, Aluigi MG, DeMarchi R et al. (1997). The beta-core fragment of human chorionic gonadotrophin inhibits growth of Kaposi's sarcoma-derived cells and a new immortalized Kaposi's sarcoma cell line. AIDS 11: 713-721.

Anastasi S, Giordano S, Sthandier O, Gambarotta G, Maione R, Comoglio P et al. (1997). A natural hepatocyte growth factor/scatter factor autocrine loop in myoblast cells and the effect of the constitutive Met kinase activation on myogenic differentiation. $J$ Cell Biol 137: 1057-1068.
(Millipore, Temecula, CA, USA) and Met (mouse anti-mouse, 1:100) (Santa Cruz Biotechnology Inc) were diluted in background reducing diluent (Dako) and applied for $1 \mathrm{~h}$ at room temperature, after the incubation with blocking serum $(3 \%$ goat serum). Fluorescent secondary antibodies Alexa Fluor goat anti-rabbit 488 (1:50) (Invitrogen, Eugene, OR, USA) and goat anti-mouse 555 (1:30) (Invitrogen) were diluted in PBS buffer and applied for $1 \mathrm{~h}$ at room temperature. Nuclei were labeled with Vectashield mounting medium (Vector Laboratories, Burlingame, CA, USA).

\section{Statistical analyses}

Statistical analyses were performed using two-tailed $t$-tests for comparison of two data sets, one-way analysis of variance for multiple data sets and two-way analysis of variance for growth curves, using the Graph Pad Prism statistics and graphing program.

\section{Conflict of interest}

The authors declare no conflict of interest.

\section{Acknowledgements}

These studies were supported by AIRC (Associazione Italiana per la Ricerca sul Cancro), ISS, Compagnia San Paolo and the MIUR. We thank Drs Monica Morini and Raffaella Dell'Eva (Istituto Nazionale per la Ricerca sul Cancro, Genova) for preliminary observations. We are indebted to Dr Paola Corradino (CBA, Genova) for literature searches and Alessandra Panvini-Rosati (Multimedica, Milan) for assistance. $\mathrm{ARC}$ is a PhD student at the Department of Structural and Functional Biology, Via Dunant 5, Varese, CF is a MIUR 'Grande Progetto Strategico' fellow.
Bardelli A, Longati P, Williams TA, Benvenuti S, Comoglio PM. (1999). A peptide representing the carboxyl-terminal tail of the met receptor inhibits kinase activity and invasive growth. $J$ Biol Chem 274: 29274-29281.

Bardelli C, Sala M, Cavallazzi U, Prat M. (2005). Agonist Met antibodies define the signalling threshold required for a full mitogenic and invasive program of Kaposi's sarcoma cells. Biochem Biophys Res Commun 334: 1172-1179.

Berthou S, Aebersold DM, Schmidt LS, Stroka D, Heigl C, Streit B et al. (2004). The Met kinase inhibitor SU11274 exhibits a selective inhibition pattern toward different receptor mutated variants. Oncogene 23: 5387-5393.

Birchmeier C, Birchmeier W, Gherardi E, Vande Woude GF. (2003). Met, metastasis, motility and more. Nat Rev Mol Cell Biol 4: $915-925$

Bladt F, Riethmacher D, Isenmann S, Aguzzi A, Birchmeier C. (1995). Essential role for the c-met receptor in the migration of myogenic precursor cells into the limb bud. Nature 376: 768-771.

Boccaccio C, Comoglio PM. (2006). Invasive growth: a MET-driven genetic programme for cancer and stem cells. Nat Rev Cancer 6: 637-645.

Bussolino F, Di Renzo MF, Ziche M, Bocchietto E, Olivero M, Naldini L et al. (1992). Hepatocyte growth factor is a potent angiogenic factor which stimulates endothelial cell motility and growth. J Cell Biol 119: 629-641. 
Cao B, Su Y, Oskarsson M, Zhao P, Kort EJ, Fisher RJ et al. (2001). Neutralizing monoclonal antibodies to hepatocyte growth factor/ scatter factor $(\mathrm{HGF} / \mathrm{SF})$ display antitumor activity in animal models. Proc Natl Acad Sci USA 98: 7443-7448.

Cao R, Bjorndahl MA, Gallego MI, Chen S, Religa P, Hansen AJ et al. (2006). Hepatocyte growth factor is a lymphangiogenic factor with an indirect mechanism of action. Blood 107: 3531-3536.

Carmeliet P, Jain RK. (2000). Angiogenesis in cancer and other diseases. Nature 407: 249-257.

Chan AM, Rubin JS, Bottaro DP, Hirschfield DW, Chedid M, Aaronson SA. (1991). Identification of a competitive HGF antagonist encoded by an alternative transcript. Science 254: $1382-1385$

Christensen JG, Schreck R, Burrows J, Kuruganti P, Chan E, Le P et al. (2003). A selective small molecule inhibitor of c-Met kinase inhibits c-Met-dependent phenotypes in vitro and exhibits cytoreductive antitumor activity in vivo. Cancer Res 63: 7345-7355.

Chu SH, Feng DF, Zhang H, Chen ET, Duan ZX, Li XY et al. (2009). c-Met-targeted RNA interference inhibits growth and metastasis of glioma U251 cells in vitro. J Neurooncol 93: 183-189.

Comoglio PM, Giordano S, Trusolino L. (2008). Drug development of MET inhibitors: targeting oncogene addiction and expedience. Nat Rev Drug Discov 7: 504-516.

Corso S, Migliore C, Ghiso E, De Rosa G, Comoglio PM, Giordano S. (2008). Silencing the MET oncogene leads to regression of experimental tumors and metastases. Oncogene 27: 684-693.

Deregibus MC, Buttiglieri S, Russo S, Bussolati B, Camussi G. (2003). CD40-dependent activation of phosphatidylinositol 3-kinase/Akt pathway mediates endothelial cell survival and in vitro angiogenesis. J Biol Chem 278: 18008-18014.

Deshayes S, Morris MC, Divita G, Heitz F. (2005). Cell-penetrating peptides: tools for intracellular delivery of therapeutics. Cell Mol Life Sci 62: 1839-1849.

Di Renzo MF, Narsimhan RP, Olivero M, Bretti S, Giordano S, Medico E et al. (1991). Expression of the Met/HGF receptor in normal and neoplastic human tissues. Oncogene 6: 1997-2003.

Dong G, Chen Z, Li ZY, Yeh NT, Bancroft CC, Van Waes C. (2001). Hepatocyte growth factor/scatter factor-induced activation of MEK and PI3K signal pathways contributes to expression of proangiogenic cytokines interleukin-8 and vascular endothelial growth factor in head and neck squamous cell carcinoma. Cancer Res $\mathbf{6 1}$ $5911-5918$.

Dong QG, Bernasconi S, Lostaglio S, De Calmanovici RW, MartinPadura I, Breviario F et al. (1997). A general strategy for isolation of endothelial cells from murine tissues. Characterization of two endothelial cell lines from the murine lung and subcutaneous sponge implants. Arterioscler Thromb Vasc Biol 17: 1599-1604.

Ebens A, Brose K, Leonardo ED, Hanson Jr MG, Bladt F, Birchmeier C et al. (1996). Hepatocyte growth factor/scatter factor is an axonal chemoattractant and a neurotrophic factor for spinal motor neurons. Neuron 17: 1157-1172.

Ebos JM, Lee CR, Cruz-Munoz W, Bjarnason GA, Christensen JG, Kerbel RS. (2009). Accelerated metastasis after short-term treatment with a potent inhibitor of tumor angiogenesis. Cancer Cell $\mathbf{1 5}$ 232-239.

Ferrara N. (2004). Vascular endothelial growth factor: basic science and clinical progress. Endocr Rev 25: 581-611.

Fischer C, Mazzone M, Jonckx B, Carmeliet P. (2008). FLT1 and its ligands VEGFB and PIGF: drug targets for anti-angiogenic therapy? Nat Rev Cancer 8: 942-956.

Foged C, Nielsen HM. (2008). Cell-penetrating peptides for drug delivery across membrane barriers. Expert Opin Drug Deliv 5: 105-117.

Folkman J. (1985). Tumor angiogenesis. Adv Cancer Res 43: 175-203.

Gherardi E, Sandin S, Petoukhov MV, Finch J, Youles ME, Ofverstedt LG et al. (2006). Structural basis of hepatocyte growth factor/scatter factor and MET signalling. Proc Natl Acad Sci USA 103: 4046-4051.

Giordano S, Maffe A, Williams TA, Artigiani S, Gual P, Bardelli A et al. (2000). Different point mutations in the met oncogene elicit distinct biological properties. FASEB J 14: 399-406.
Goh PP, Sze DM, Roufogalis BD. (2007). Molecular and cellular regulators of cancer angiogenesis. Curr Cancer Drug Targets 7: $743-758$

Grant DS, Kleinman HK, Goldberg ID, Bhargava MM, Nickoloff BJ, Kinsella JL et al. (1993). Scatter factor induces blood vessel formation in vivo. Proc Natl Acad Sci USA 90: 1937-1941.

Grant DS, Tashiro K, Segui-Real B, Yamada Y, Martin GR, Kleinman HK. (1989). Two different laminin domains mediate the differentiation of human endothelial cells into capillary-like structures in vitro. Cell 58: 933-943.

Graziani A, Gramaglia D, Cantley LC, Comoglio PM. (1991). The tyrosine-phosphorylated hepatocyte growth factor/scatter factor receptor associates with phosphatidylinositol 3-kinase. J Biol Chem 266: 22087-22090.

Gupta B, Levchenko TS, Torchilin VP. (2005). Intracellular delivery of large molecules and small particles by cell-penetrating proteins and peptides. Adv Drug Deliv Rev 57: 637-651.

Jun HT, Sun J, Rex K, Radinsky R, Kendall R, Coxon A et al. (2007). AMG 102, a fully human anti-hepatocyte growth factor/scatter factor neutralizing antibody, enhances the efficacy of temozolomide or docetaxel in U-87MG cells and xenografts. Clin Cancer Res 13: 6735-6742.

Khwaja A, Lehmann K, Marte BM, Downward J. (1998). Phosphoinositide 3-kinase induces scattering and tubulogenesis in epithelial cells through a novel pathway. J Biol Chem 273: 18793-18801.

Kim KJ, Wang L, Su YC, Gillespie GY, Salhotra A, Lal B et al. (2006). Systemic anti-hepatocyte growth factor monoclonal antibody therapy induces the regression of intracranial glioma xenografts. Clin Cancer Res 12: 1292-1298.

Kleinman HK, McGarvey ML, Hassell JR, Star VL, Cannon FB, Laurie GW et al. (1986). Basement membrane complexes with biological activity. Biochemistry 25: 312-318.

Lock LS, Frigault MM, Saucier C, Park M. (2003). Grb2-independent recruitment of Gabl requires the C-terminal lobe and structural integrity of the Met receptor kinase domain. $J$ Biol Chem 278: 30083-30090.

Loges S, Mazzone M, Hohensinner P, Carmeliet P. (2009). Silencing or fueling metastasis with VEGF inhibitors: antiangiogenesis revisited. Cancer Cell 15: 167-170.

Longati P, Bardelli A, Ponzetto C, Naldini L, Comoglio PM. (1994). Tyrosines1234-1235 are critical for activation of the tyrosine kinase encoded by the MET proto-oncogene (HGF receptor). Oncogene $\mathbf{9}$ : $49-57$.

Lou X, Zhou Q, Yin Y, Zhou C, Shen Y. (2009). Inhibition of the met receptor tyrosine kinase signaling enhances the chemosensitivity of glioma cell lines to CDDP through activation of p38 MAPK pathway. Mol Cancer Ther 8: 1126-1136.

Matsumoto K, Nakamura T. (2003). NK4 (HGF-antagonist/angiogenesis inhibitor) in cancer biology and therapeutics. Cancer Sci 94 : 321-327.

Mazzone M, Basilico C, Cavassa S, Pennacchietti S, Risio M, Naldini L et al. (2004). An uncleavable form of pro-scatter factor suppresses tumor growth and dissemination in mice. J Clin Invest 114: 1418-1432.

Michieli P, Mazzone M, Basilico C, Cavassa S, Sottile A, Naldini L et al. (2004). Targeting the tumor and its microenvironment by a dual-function decoy Met receptor. Cancer Cell 6: 61-73.

Morotti A, Mila S, Accornero P, Tagliabue E, Ponzetto C. (2002). K252a inhibits the oncogenic properties of Met, the HGF receptor. Oncogene 21: 4885-4893.

Morris MC, Deshayes S, Heitz F, Divita G. (2008). Cell-penetrating peptides: from molecular mechanisms to therapeutics. Biol Cell 100: 201-217.

Nishino T, Hisha H, Nishino N, Adachi M, Ikehara S. (1995). Hepatocyte growth factor as a hematopoietic regulator. Blood $\mathbf{8 5}$ : 3093-3100.

Paez-Ribes M, Allen E, Hudock J, Takeda T, Okuyama H, Vinals F et al. (2009). Antiangiogenic therapy elicits malignant progression of tumors to increased local invasion and distant metastasis. Cancer Cell 15: 220-231. 
Paranjpe S, Bowen WC, Bell AW, Nejak-Bowen K, Luo JH, Michalopoulos GK. (2007). Cell cycle effects resulting from inhibition of hepatocyte growth factor and its receptor c-Met in regenerating rat livers by RNA interference. Hepatology 45: 1471-1477.

Pennacchietti S, Michieli P, Galluzzo M, Mazzone M, Giordano S, Comoglio PM. (2003). Hypoxia promotes invasive growth by transcriptional activation of the met protooncogene. Cancer Cell 3: $347-361$.

Ponzetto C, Bardelli A, Maina F, Longati P, Panayotou G, Dhand R et al. (1993). A novel recognition motif for phosphatidylinositol 3-kinase binding mediates its association with the hepatocyte growth factor/scatter factor receptor. Mol Cell Biol 13: 4600-4608.

Ponzetto C, Bardelli A, Zhen Z, Maina F, dalla Zonca P, Giordano S et al. (1994). A multifunctional docking site mediates signaling and transformation by the hepatocyte growth factor/scatter factor receptor family. Cell 77: 261-271.

Prat M, Crepaldi T, Pennacchietti S, Bussolino F, Comoglio PM. (1998). Agonistic monoclonal antibodies against the Met receptor dissect the biological responses to HGF. J Cell Sci 111(Part 2): 237-247.

Prat M, Narsimhan RP, Crepaldi T, Nicotra MR, Natali PG, Comoglio PM. (1991). The receptor encoded by the human c-MET oncogene is expressed in hepatocytes, epithelial cells and solid tumors. Int $J$ Cancer 49: 323-328.

Schmidt C, Bladt F, Goedecke S, Brinkmann V, Zschiesche W, Sharpe $M$ et al. (1995). Scatter factor/hepatocyte growth factor is essential for liver development. Nature 373: 699-702.

Sengupta S, Gherardi E, Sellers LA, Wood JM, Sasisekharan R, Fan TP. (2003). Hepatocyte growth factor/scatter factor can induce angiogenesis independently of vascular endothelial growth factor. Arterioscler Thromb Vasc Biol 23: 69-75.
Silvagno F, Follenzi A, Arese M, Prat M, Giraudo E, Gaudino G et al. (1995). In vivo activation of met tyrosine kinase by heterodimeric hepatocyte growth factor molecule promotes angiogenesis. Arterioscler Thromb Vasc Biol 15: 1857-1865.

Stewart KM, Horton KL, Kelley SO. (2008). Cell-penetrating peptides as delivery vehicles for biology and medicine. Org Biomol Chem 6: 2242-2255.

Uehara Y, Minowa O, Mori C, Shiota K, Kuno J, Noda T et al. (1995). Placental defect and embryonic lethality in mice lacking hepatocyte growth factor/scatter factor. Nature 373: 702-705.

Vigna E, Pacchiana G, Mazzone M, Chiriaco C, Fontani L, Basilico C et al. (2008). Active' cancer immunotherapy by anti-Met antibody gene transfer. Cancer Res 68: 9176-9183.

You WK, McDonald DM. (2008). The hepatocyte growth factor/cMet signaling pathway as a therapeutic target to inhibit angiogenesis. BMB Rep 41: 833-839.

Zhang YW, Su Y, Volpert OV, Vande Woude GF. (2003). Hepatocyte growth factor/scatter factor mediates angiogenesis through positive VEGF and negative thrombospondin 1 regulation. Proc Natl Acad Sci USA 100: 12718-12723.

Zou HY, Li Q, Lee JH, Arango ME, McDonnell SR, Yamazaki S et al. (2007). An orally available small-molecule inhibitor of c-Met, PF-2341066, exhibits cytoreductive antitumor efficacy through antiproliferative and antiangiogenic mechanisms. Cancer Res 67: $4408-4417$.

This work is licensed under the Creative Commons Attribution-NonCommercial-No Derivative Works 3.0 Unported License. To view a copy of this license, visit http://creativecommons.org/licenses/by-nc-nd/3.0/

Supplementary Information accompanies the paper on the Oncogene website (http://www.nature.com/onc) 